\title{
Antidiabetic properties and metal analysis of Bombax ceiba flower extracts
}

\author{
Mohd Amin Mir ${ }^{1 *}$, Bilal Ahmad Mir ${ }^{3}$, Anil Bisht ${ }^{2}$, Zainab Rao ${ }^{3}$ and Dhyal Singh ${ }^{2}$ \\ ${ }^{1}$ Research Scholar at Uttarakhand Technical University, India \\ ${ }^{2}$ Department of Zoology, Uttaranchal College of Bio-medical sciences and Hospital, India \\ ${ }^{3}$ Department of Microbiology, Uttaranchal College of Bio-medical sciences and Hospital, India
}

Submission: March 08, 2017; Published: March 20, 2017

*Corresponding author: Mohd Amin Mir, Research Scholar at Uttarakhand Technical University, India, Tel: 9897635334; Email: mohdaminmir@gmail.com

\begin{abstract}
The plant may be considered a bio-synthetic laboratory, not only for the bio-chemicals such as carbohydrates, protein, and lipid that are utilized as food by man, but also for a multitude of compounds like glycosides, alkaloids, tannins etc, that exerts physiological effects. The compound those are responsible for therapeutic effects are usually the secondary metabolite. Bombex ceiba plant extracts have been evaluated for its antidiabetic properties by in-vitro inhabitation of alpha amylase and alpha glucosidase enzymes. The results so far obtained are encouraging by showing inhibition of these enzymes to a large extent. The water and ethanolic extracts of all the plant parts (thalamus and flower) show the highest inhibition as compared to DCM extracts.

The corresponding IC50 values are as thalamus DCM extract 36.22, ethanolic extract 35.32, and water extract 31.31and the flower DCM extract 38.13, ethanolic extract 35.23, and water extract 33.00. The water, ethanolic and DCM extract of thalamus shows the concentration of sodium as 340, 310, $120(\mathrm{ppm})$, potassium as 151, 180, $98(\mathrm{ppm})$, lithium 31, 25, $11(\mathrm{ppm})$ and that of calcium 110, 80, 89 (ppm). The water, ethanolic and DCM extract of flower shows the concentration of sodium as 300, 295, 95 (ppm), potassium as 149, 175, 81 (ppm), lithium 28, 20, 05 (ppm) and that of calcium 95, 75, 64 (ppm).
\end{abstract}

Keywords: Bombex ceiba; Metal ions; Plant extracts; IC50 values; Flower; Thalamus

\section{Introduction}

Medicinal plants are the plants used for centuries as remedies for human diseases because they contain components of therapeutic value. About $80 \%$ of world population relies on the use of traditional medicine which is predominantly based on plant material.

Semal is called Kings of the Forest due to their massive size and showy flowers. It is a large deciduous tree with a straight cylindrical stem and horizontally spreading branches in whorls. This horizontally branching system in whorls, large size and the buttress at the base are the first seen characteristics to distinguish the species in the forest. The tree reaches up to 40 meter in height and 2 meter in diameter with the clear bole of 24-30 meter. Large trees are invariably buttressed at the base. Stem buttresses at the base and go up to 5-6 meter in height. Family: Braginaceaae.

The Bombes ceiba possesses the active constituents which have a direct role in the management of diabetes mellitus as compiled by Rawat Mukesh and Parmar Namita [1]. Bombax ceiba Linn is a popular plant among native communities for its medicinal properties. The root is specially used for debility and impotence. A case study of a patient of involuntary weight loss without any detectable cause who was administered $1.5 \mathrm{~g}$ of $\mathrm{B}$. ceiba root powder with milk for 24 weeks as the study carried out by S. K. Verma, Vartika Jain, and S. S. Katewa [2].

Thestudy by Verma Rameshwar, Devre Kishor, Gangrade Tushar, Gore Siddharth, Gour Sudarshan [3] provides an insight on pharmacological, phytochemical properties and therapeutic benefits of the plant. A study undertaken by Bhushan Gandhare, Nikhil Soni, Hemant J. Dhongade [4] evaluated the antioxidant potential of bark of Bombax ceiba. The study by Roja Sri Donipati, Dr. M. V. Rama Rao and Dr. P. Subhasini [5], mentioned the microbial activity of Hexane, Methanol and chloroform extracts of flowers of Bombax ceiba for potential antimicrobial activity against various bacterial strains. The whole plant of Bombax ceiba used as traditional folk medicines for the treatment of anti- 
dysentric, anti-diahorreal and anti-pyretic effects. Bombax ceiba Linn contains glycosides, tannins, flavonoid, b-sitosterol, lupeol as shown by Garg Nitika, Meena Ajay, Nainjaspreet [6].

\section{Experiment work}

A. Study area and plant collection: The Bombax ceiba flowers were collected from the FRI Dehradun. The Bombax ceiba flowers were shade dried and powdered in mixture. The powder of Bombax ceiba was used for experiment.

B. Extraction: 50 gms of each Bombax ceiba flower petals and the thalamus were weighed separately and accurately and then extracted in a Soxhlet Apparatus using thimble in order to get the pure form of extract. Various solvents were used depending upon their polarity index with increasing polarity (dichloromethane, ethanol and water).

\section{a) Extraction A:}

The sample was extracted with a particular solvent (viz dichloromethane) in a Soxhlet apparatus for a required period, till no extract was coming out of the sample, as being examined by taking a small amount of the extracted solvent from the main chamber of the Soxhlet apparatus over the watch glass for the appearance of precipitate. After the Extraction with dichloromethane, the extract solution was subjected to filtration to remove the residue from extract. The filtrate was them then collected and evaporated to remove the volatile solvent to its $1 / 4$ volume on water bath at a suitable temperature. The whole filtrate was then made in solid form (powdered) after being kept in an oven. The residue was collected, and subjected to further extraction process using ethanol as an extractants and by using water as an extractant decoction method was employed.

\section{Flame Photometric Estimation of $\mathrm{Na}, \mathrm{K}, \mathrm{Ca}, \mathrm{Li}$}

Flame Photometer Model - 1385 is a microprocessor based unit designed for medical application. The microprocessor provides automation in operation, measurement and end-result presentation. The unit can do the estimation of Sodium $\left(\mathrm{Na}^{+}\right)$, potassium $\left(\mathrm{K}^{+}\right)$, Lithium $\left(\mathrm{Li}^{+}\right)$and calcium $(\mathrm{Ca}+2)$ in single aspiration of a sample as per Whitney EN, Rolfes SR and St. Paul, MN - 1996.

\section{A. Preparation of Various Extract}

For preparation of water extract, $10 \mathrm{mg}$ of the extracts of flower (DCM, Ethanol, and Water) were separately mixed with the $10 \mathrm{ml}$ of water. The extracts were completely exhausted by adding small quantities of water and filtering off every time in a successive manner, to yield final volume of 1 liter.

\section{B. Preparation of Mixed Standard Solutions.}

Mixed standard solution of $\mathrm{Na}^{+}, \mathrm{K}^{+}, \mathrm{Ca}^{+2}$ and $\mathrm{Li}^{+2}$ were prepared by dissolving $254.2 \mathrm{mg}$ of $\mathrm{NaCl}, 190.6 \mathrm{mg}$ of $\mathrm{KCl}, 276.9$ $\mathrm{mg}$ of $\mathrm{CaCl}^{2}$ and $184.3 \mathrm{mg}$ of $\mathrm{Li} 2 \mathrm{SO} 4 . \mathrm{H}^{2} \mathrm{O}$ in 1 litre of water, so it gives $100 \mathrm{ppm}$ (4.35 millimole/lit.) of $\mathrm{Na}+, 100 \mathrm{ppm}(2.558$ millimole/lit.) of $\mathrm{K}+, 100$ ppm (2.495 millimole/lit.) of $\mathrm{Ca}+2$ and
20 ppm (2.88 millimole/lit.) of Li+2 solution.

\section{In-vitro inhibition of alpha-amylase and alpha- glucosidase by plant extracts}

\section{a) Inhibition of alpha amylase Enzyme}

Alpha amylase is an enzyme that hydrolyses alpha-bonds of large alpha linked polysaccharide such as glycogen and starch to yield glucose and maltose. Alpha amylase inhibitory activity was based on the starch iodine method that was originally developed by Laila A. Shekib, Samir M. El-Iraqui, Taisser M. Abo-Bakr [7]. In alpha amylase inhibition method $1 \mathrm{ml}$ substrate- potato starch $(1 \% \mathrm{w} / \mathrm{v})$, different concentrations of (Acarbose std drug / Plant extracts), $1 \mathrm{ml}$ of alpha amylase enzyme $(1 \% \mathrm{w} / \mathrm{v})$ and $2 \mathrm{ml}$ of acetate buffer $(0.1 \mathrm{M}, 7.2 \mathrm{pH})$ was added. NOTE- Potato starch solution, alpha amylase solution and drug solution was prepared in acetate buffer. The above mixture was incubated for $1 \mathrm{hr}$. Then $0.1 \mathrm{ml}$ Iodine-iodide indicator (635mg Iodine and $1 \mathrm{gm}$ potassium iodide in $250 \mathrm{ml}$ distilled water) was added in the mixture. Absorbance was taken at $565 \mathrm{~nm}$ in UV-Visible spectroscopy. \% inhibition was calculated and all the tests were performed in triplicate.

\section{b) Inhibition of alpha-glucosidase Enzyme}

The inhibitory activity was determined by incubating a solution of starch substrate ( $2 \% \mathrm{w} / \mathrm{v}$ maltose or sucrose) $1 \mathrm{ml}$ with $0.2 \mathrm{M}$ Tris buffer $\mathrm{pH} 8.0$ and various concentration of plant extract for $5 \mathrm{~min}$ at $37^{\circ} \mathrm{C}$. The reaction was initiated by adding $1 \mathrm{ml}$ of alpha-glucosidase enzyme $(1 \mathrm{U} / \mathrm{ml})$ to it followed by incubation for $40 \mathrm{~min}$ at $35^{\circ} \mathrm{C}$. Then the reaction was terminated by the addition of $2 \mathrm{ml}$ of $6 \mathrm{~N} \mathrm{HCl}$. Then the intensity of the colour was measured at $540 \mathrm{~nm}[8]$.

\section{c) Calculation of $\mathbf{5 0 \%}$ Inhibitory Concentration ( IC $\left._{50}\right)$}

The concentration of the plant extracts required to scavenge $50 \%$ of the radicals $\left(\mathrm{IC}_{50}\right)$ was calculated by using the percentage scavenging activities at five different concentrations of the extract. Percentage inhibition (\% I) was calculated by

$$
\% \mathrm{I}=(\text { Ac-As) } / \text { Ac X } 100 \text { [9] }
$$

Where Ac is the absorbance of the control and As is the absorbance of the sample.

\section{Observations and Result}

\section{i. Antidiabetic Property of Bombax ceiba plant extracts by inhibition of Alpha-amylase)}

The alpha-amylase inhibition of various plant extracts (flower and thalamus) extracts have been analyzed, and it was found that (water extract of thalamus) posses the highest inhibition potential followed by (ethanolic extract of thalamus). The percentage inhibition by plant extracts was found to be concentration dependent, percentage inhibition increases with the increase in the concentration of the plant extracts. The $\mathrm{IC}_{50}$ value was determined from the straight line graph. The $\mathrm{IC}_{50}$ value of all the plant extracts was found lesser than the reference 


\section{Global Journal of Addiction \& Rehabilitation Medicine}

compound (ACAROSE). The $\mathrm{IC}_{50}$ value of various plant extracts follows the order (water extract of thalamus, ethanolic extract of thalamus, ethanolic extract of flower, DCM extract of thalamus, water extract of flower and DCM extract of flower) was found to be $(32.95,33.45,33.85,34.95,35.15$ and 35.65$)$ respectively and are presented in (Tables 1-7).

Table 1: Report of \% inhibition of (alpha-amylase) by ACAROSE Standard for in vitro antidiabetic studies).

\begin{tabular}{|c|c|c|c|}
\hline S. No & $\begin{array}{c}\text { Conc. of } \\
\text { Sample } \\
(\boldsymbol{\mu g} / \mathbf{m l})\end{array}$ & \begin{tabular}{c}
\multirow{2}{*}{ \% of } \\
Inhibition
\end{tabular} & \multirow{2}{*}{ IC $_{\mathbf{5 0}}$} \\
\hline 1 & 10 & 35.12 & \multirow{2}{*}{29.12} \\
\hline 2 & 20 & 56.22 & \multirow{2}{*}{70.23} \\
\hline 3 & 30 & 87.22 & \\
\hline 5 & 40 & 93.97 \\
\hline
\end{tabular}

Table 2: Report of \% inhibition of (alpha-amylase) by dichloromethane extract of flower.

\begin{tabular}{|c|c|c|}
\hline Conc. $(\boldsymbol{\mu g} / \mathbf{m l})$ & \% Inhibition & \multirow{2}{*}{ IC $_{\mathbf{5 0}}$} \\
\hline 10 & 41.15 & \\
\hline 20 & 45.13 & \\
\hline 30 & 45.26 & \multirow{2}{*}{34.35} \\
\hline 40 & 62.62 & \\
\hline 50 & 74.11 & \\
\hline
\end{tabular}

Table 3: Report of \% inhibition of (alpha-amylase) by Ethanolic extract of flower.

\begin{tabular}{|c|c|c|}
\hline Conc. $(\boldsymbol{\mu g} / \mathbf{m l})$ & \% Inhibition & \multirow{2}{*}{ IC $_{\mathbf{5 0}}$} \\
\hline 10 & 17.16 & \\
\hline 20 & 47.25 & \multirow{2}{*}{32.15} \\
\hline 30 & 56.19 & \\
\hline 40 & 72.27 & \\
\hline 50 & 86.33 & \\
\hline
\end{tabular}

Table 4: Report of \% inhibition of (alpha-amylase) by water extract of flower.

\begin{tabular}{|c|c|c|}
\hline Conc. $(\boldsymbol{\mu g} / \mathbf{m l})$ & \% Inhibition & \multirow{2}{*}{ IC $_{50}$} \\
\hline 10 & 11.51 & \\
\hline 20 & 26.83 & \\
\hline 30 & 31.61 & \multirow{2}{*}{34.25} \\
\hline 40 & 42.36 & \\
\hline 50 & 60.34 & \\
\hline
\end{tabular}

Table 5: Report of \% inhibition of (alpha-amylase) by dichloromethane extract of thalamus

\begin{tabular}{|c|c|c|}
\hline Conc. In $\boldsymbol{\mu g} / \mathbf{m l}$ & \% Inhibition & IC $_{\mathbf{5 0}}$ \\
\hline 10 & 33.65 & \\
\hline 20 & 48.08 & \\
\hline 30 & 50 & \multirow{2}{*}{34.95} \\
\hline 40 & 69.23 & \\
\hline 50 & 96.15 & \\
\hline
\end{tabular}

Table 6: Report of \% inhibition of (alpha-amylase) by dichloromethane extract of thalamus

\begin{tabular}{|c|c|c|}
\hline Conc. In $\boldsymbol{\mu g} / \mathbf{m l}$ & \% Inhibition & \multirow{2}{*}{ IC $_{\mathbf{5 0}}$} \\
\hline 10 & 33.65 & \\
\hline 20 & 47.11 & \multirow{2}{*}{32.45} \\
\hline 30 & 77.85 & \\
\hline 40 & 87.55 & \\
\hline 50 & 88.46 & \\
\hline
\end{tabular}

Table 7:Report of \% inhibition of (alpha-amylase) by water extract of thalamus.

\begin{tabular}{|c|c|c|}
\hline Conc. $\mathbf{I n} \boldsymbol{\mu g} / \mathbf{m l}$ & \% Inhibition & \multirow{2}{*}{ IC $_{\mathbf{5 0}}$} \\
\hline 10 & 32.49 & \\
\hline 20 & 45.25 & \\
\hline 30 & 65.15 & \multirow{2}{*}{31.95} \\
\hline 40 & 71.13 & \\
\hline 50 & 79.34 & \\
\hline
\end{tabular}

ii. Antidiabetic Property of Various Extracts of Bombax ceiba by inhibition of (Alpha-glycosidase)

The Bombax ceiba plant extracts (Flower, Thalamus) have been analysed for the inhibition of (alpha glucosidase). The inhibition percentage was determined by Spectrophotometric method, and $\mathrm{IC}_{50}$ value of all the plant extracts was determined. The lower $\mathrm{IC}_{50}$ value indicates higher inhibition percentage. Among the all plant extracts the higher inhibition of alpha glucosidase inhibition was shown by (Water extract of flower) (Figures 1-11), and the $\mathrm{IC}_{50}$ value as determined was found to be (36.2). The various plant extracts follow the order as per their inhibition potential as (water extract of flower, Ethanol Extract of Thalamus, water extract of thalamus, ethanolic extract of flower, DCM extract of flower and DCM extract of Thalamus). The percentage inhibition was found to be concentration dependent as the value of percentage inhibition increases correspondingly with the increase in the concentration of plant. The IC50 values of all the plant extracts have been found to be less than the reference compound (ACAROSE) (Tables 8-11) as per their percentage inhibition is taken into consideration. The IC50 value of various plant extracts is as $(37.2,36.82,36.21,37.3,36.3$ 36.5) respectively for (DCM extract of flower, ethanolic extract of flower, water extract of flower, DCM extract of thalamus, ethanolic extract of thalamus and water extract of thalamus) (Tables 12-14). 


\section{Global Journal of Addiction \& Rehabilitation Medicine}

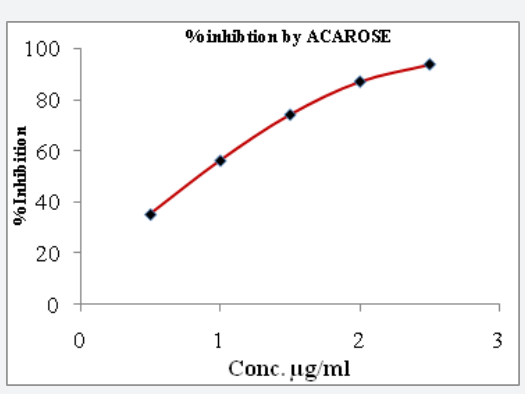

Figure 1: Represents the (\% Inhibition of alpha amylase enzyme) by ACAROSE.

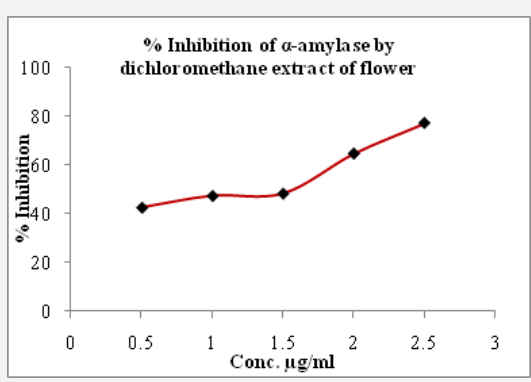

Figure 2: Represents the (\% Inhibition of alpha amylase enzyme) by dichloromethane extract of flower.

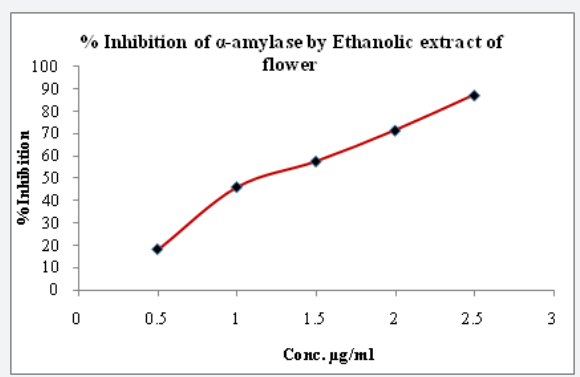

Figure 3: Represents the (\% Inhibition of alpha amylase enzyme) by Ethanolic extract of flower

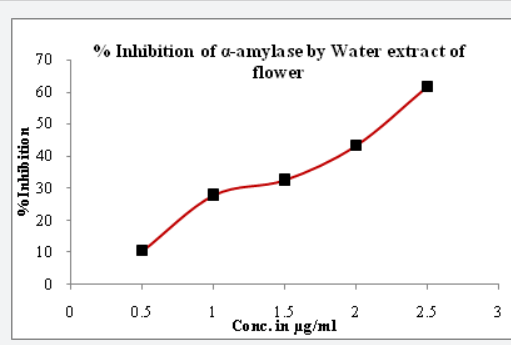

Figure 4: Represents the (\% Inhibition of alpha amylase enzyme) water extract of flower.

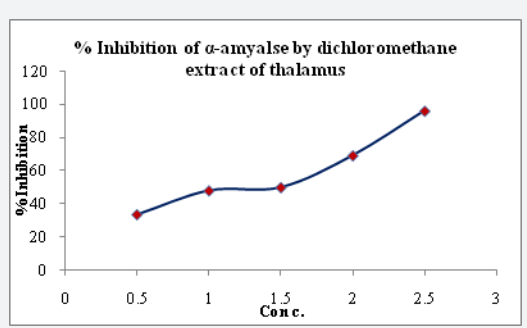

Figure 5: Represents the (\% Inhibition of alpha amylase enzyme) dichloromethane extract of thalamus.

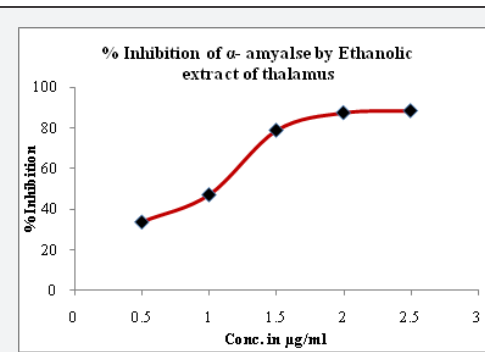

Figure 6: Represents the (\% Inhibition of alpha amylase enzyme) ethanolic extract of thalamus.

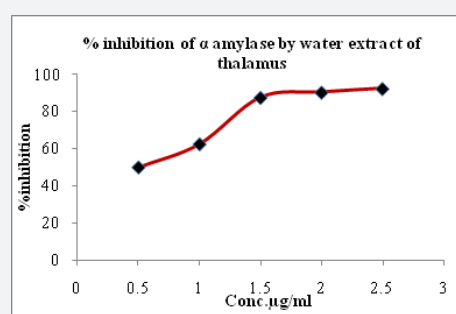

Figure 7: Represents the (\% Inhibition of alpha amylase enzyme) by water extract of thalamus.

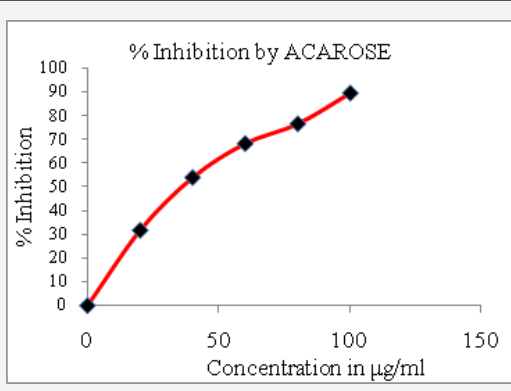

Figure 8: Represents the (\% Inhibition of alpha glycosidase enzyme) by (ACAROSE).

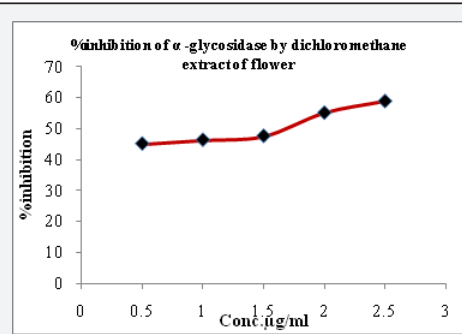

Figure 9: Represents the (\% Inhibition of alpha glycosidase enzyme) by Dichloromethane extract of flower.

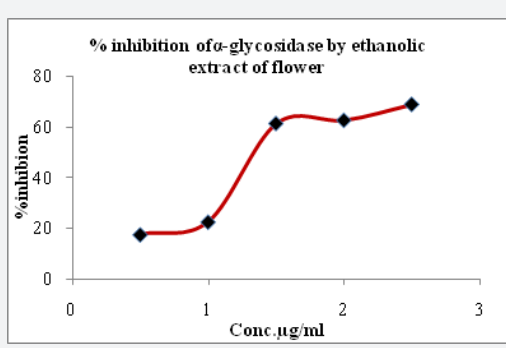

Figure 10: Represents the (\% Inhibition of alpha glycosidase enzyme) by Ethanolic extract of flower. 


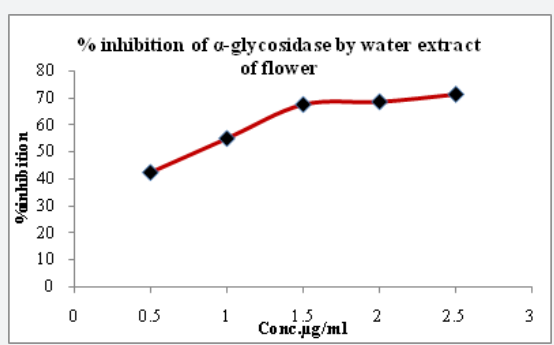

Figure 11: Represents the (\% Inhibition of alpha glycosidase enzyme) by water extract of flower.

Table 8:Report of \% inhibition of (alpha glucosidase) by (Acarbose).

\begin{tabular}{|c|c|c|c|}
\hline S. No & $\begin{array}{c}\text { Conc. of } \\
\text { Sample }(\boldsymbol{\mu g} / \\
\mathbf{m l})\end{array}$ & \begin{tabular}{c}
\multirow{2}{*}{$\mathbf{I C}_{\mathbf{5 0}}$} \\
Inhibition
\end{tabular} & \multirow{2}{*}{ of } \\
\cline { 1 - 2 } 1 & 10 & 31.7 & \multirow{2}{*}{30.5} \\
\hline 2 & 20 & 48.9 & \multirow{2}{*}{55.2} \\
\hline 3 & 30 & 76.5 & \\
\hline 4 & 40 & 89.4 & \\
\hline 5 & 50 & \\
\hline
\end{tabular}

Table 9:Report of \% inhibition of (alpha glucosidase) by dichloromethane extract of flower.

\begin{tabular}{|c|c|c|}
\hline Conc. In $\boldsymbol{\mu g} / \mathbf{m l}$ & \% Inhibition & IC $_{\mathbf{5 0}}$ \\
\hline 10 & 45.23 & \\
\hline 20 & 45.25 & \\
\hline 30 & 46.15 & \multirow{2}{*}{36.22} \\
\hline 40 & 55.00 & \\
\hline 50 & 59.75 & \\
\hline
\end{tabular}

Table 10:Report of \% inhibition of (alpha glucosidase) by Ethanolic extract of flower.

\begin{tabular}{|c|c|c|}
\hline Conc. In $\boldsymbol{\mu g} / \mathbf{m l}$ & \% Inhibition & \multirow{2}{*}{ IC $_{\mathbf{5 0}}$} \\
\hline 10 & 19.15 & \\
\hline 20 & 21.12 & \multirow{2}{*}{35.32} \\
\hline 30 & 59.15 \\
\hline 40 & 60.15 & \\
\hline 50 & 67.45 & \\
\hline
\end{tabular}

Table 11:Report of $\%$ inhibition of (alpha glucosidase) by water extract of flower.

\begin{tabular}{|c|c|c|}
\hline Conc. In $\boldsymbol{\mu g} / \mathbf{m l}$ & \% Inhibition & IC $_{\mathbf{5 0}}$ \\
\hline 10 & 35.25 & \\
\hline 20 & 51.54 & \\
\hline 30 & 65.15 & \multirow{2}{*}{31.31} \\
\hline 40 & 66.52 & \\
\hline 50 & 70.15 & \\
\hline
\end{tabular}

Table 12:Report of \% inhibition of (alpha glucosidase) by dichloromethane extract of thalamus.

\begin{tabular}{|c|c|c|}
\hline Conc. $\mathbf{I n} \boldsymbol{\mu g} / \mathbf{m l}$ & \% Inhibition & \multirow{2}{*}{ IC $_{\mathbf{5 0}}$} \\
\hline 10 & 37.23 & \multirow{2}{*}{3} \\
\hline 20 & 41.52 & \multirow{2}{*}{38.13} \\
\hline 30 & 49.35 & \\
\hline 40 & 57.25 & \\
\hline 50 & 76.55 & \\
\hline
\end{tabular}

Table 13:Report of \% inhibition of (alpha glucosidase) by ethanolic extract of thalamus.

\begin{tabular}{|c|c|c|}
\hline Conc. $\mathbf{I n} \boldsymbol{\mu g} / \mathbf{m l}$ & \% Inhibition & \multirow{2}{*}{ IC $_{\mathbf{5 0}}$} \\
\hline 10 & 37.25 & \\
\hline 20 & 48.25 & \\
\hline 30 & 53.25 & \multirow{2}{*}{35.23} \\
\hline 40 & 54.15 & \\
\hline 50 & 63.25 & \\
\hline
\end{tabular}

Table 14:Report of $\%$ inhibition of (alpha glucosidase) by water extract of thalamus.

\begin{tabular}{|c|c|c|}
\hline Conc. In $\boldsymbol{\mu g} / \mathbf{m l}$ & \% Inhibition & \multirow{2}{*}{ IC $_{\mathbf{5 0}}$} \\
\hline 10 & 35.51 & \multirow{2}{*}{3} \\
\hline 20 & 48.54 & \multirow{2}{*}{33.00} \\
\hline 30 & 56.52 & \\
\hline 40 & 63.45 & \\
\hline 50 & 68.45 & \\
\hline
\end{tabular}

\section{iii. Metal Analyses by Flame Photometry}

The metals which have been analysed by Flame Photometry include ( $\mathrm{Na}, \mathrm{K}, \mathrm{Li}$ and $\mathrm{K}$ ). In flame photometric analysis the elements analysed were burnt in presence of a given flame, the burnt element gives its characteristic coloured flame which is being analysed. All the metal concentrations are in (ppm) units and are tabulated in (Tables $15 \& 16$ ). The graph traced between metal ion concentration and plant extracts are shown in (Figures 12-16).

Table 15: Report of Flame Photometric Analysis of Metal Ions (in ppm) in (water, ethanolic and DCM) Flower Extracts of Bombax ceiba.

\begin{tabular}{|c|c|c|c|c|}
\hline \multirow{2}{*}{ Sample Name } & \multicolumn{4}{|c|}{ Metal Ions (ppm) } \\
\cline { 2 - 5 } & Na & K & Li & Ca \\
\hline Water Extract of Flowers & 340 & 151 & 31 & 110 \\
\hline $\begin{array}{c}\text { Ethanolic Extract of } \\
\text { Flowers }\end{array}$ & 310 & 180 & 25 & 80 \\
\hline DCM Extract of Flowers & 120 & 98 & 11 & 89 \\
\hline
\end{tabular}


Table 16: Report of Flame Photometric Analysis of Metal lons (in ppm) in (water, ethanolic and DCM) Thalamus Extracts of Bombax ceiba.

\begin{tabular}{|c|c|c|c|c|}
\hline & \multicolumn{3}{|c|}{ Metal Ions (ppm) } \\
\multirow{2}{*}{$\begin{array}{c}\text { Sample } \\
\text { Name }\end{array}$} & Na & K & Li & Ca \\
\cline { 2 - 5 } & 300 & 149 & 28 & 95 \\
\hline $\begin{array}{c}\text { Water } \\
\text { thtract of } \\
\text { thalamus }\end{array}$ & 295 & 175 & 20 & 75 \\
\hline $\begin{array}{c}\text { Ethanolic } \\
\text { Extract of } \\
\text { thalamus }\end{array}$ & 95 & 81 & 05 & 64 \\
\hline $\begin{array}{c}\text { DCM } \\
\text { Extract of } \\
\text { thalamus }\end{array}$ & & & \\
\hline
\end{tabular}

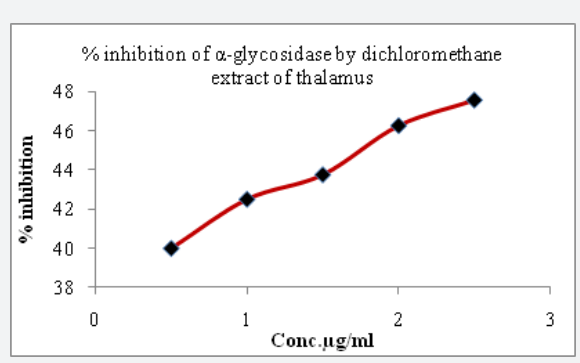

Figure 12: Represents the (\% Inhibition of alpha glycosidase enzyme) by dichloromethane extract of thalamus.

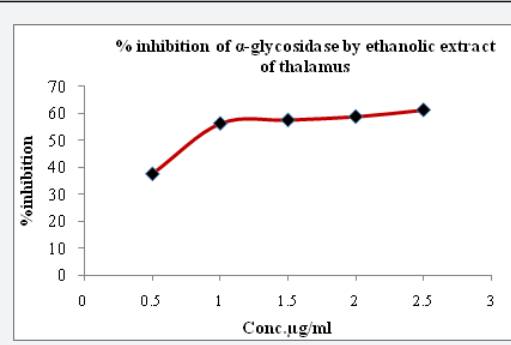

Figure 13: Represents the (\% Inhibition of alpha glycosidase enzyme) by Ethanolic extract of thalamus.

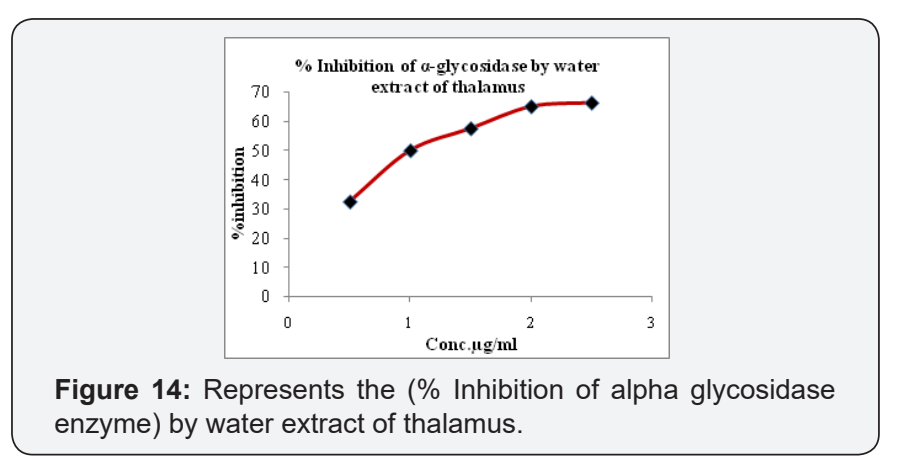

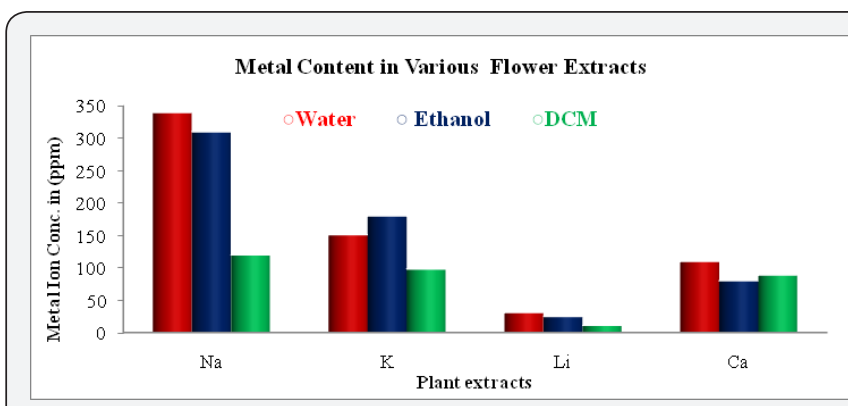

Figure 15: Represents the (Metal Content) of (Water, Ethanol, DCM) Extracts of Bombax ceiba flowers by Flame Photometry.

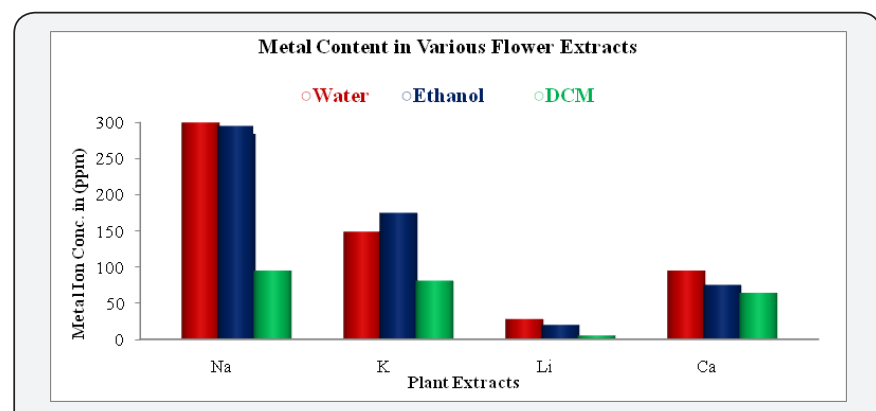

Figure 16: Represents the (Metal Content) of (Water, Ethanol, DCM) Extracts of Bombax ceiba thalamus by Flame Photometry.

\section{Discussion}

Bombex ceba plant extracts have been evaluated for its antidiabetic properties by in-vitro inhabitation of alpha amylase and alpha glucosidase enzymes. The results so far obtained are encouraging by showing inhibition of these enzymes to a large extent. The ethanol and water extracts of all the plant parts show the highest inhibition as compared to DCM extracts. The results obtained in this study are in line with the already obtained results for the antidiabetic potential of the plant. The polar solvent extracts being showing the highest potential against the alpha amylase and alpha glucosidase enzyme. The plant-based antidiabetic drugs or agents contains diversity of major active constituents such as phenols, Coumarins, lignans, terpenoids, carotenoids, glycosides, flavonoids, organic acids, alkaloids and xanthenes.

The highest concentration of potassium in stem, root and flower extracts were found to be 151, 180, and $98 \mathrm{ppm}$ respectively. The concentration is within the limit set by FAO/WHO., 1984 [10]. It helps to promote efficient cognitive functioning by playing a significant role in getting oxygen to the brain as reported by Charlene J. Nuble 2005 [11]. The highest sodium ion concentration in the water, ethanolic and DCM extracts have been found to be 340,310 and $120 \mathrm{ppm}$ respectively and is within the limits of FAO/WHO., 1984 [10]. Sodium $(\mathrm{Na})$ is the major extracellular cation and it plays a role in body fluid distribution.

Calcium strengthens your bones, particularly before you are 35 years old. Recommended Dietary Allowances 1989 [12] 
mentioned that (99\%) of calcium is found in bones and teeth. The calcium concentration in the stem, root and flower extracts have been found to be 110,80 and 89 ppm respectively. The calcium concentration in the concerned plant extracts is sufficient if used as a supplement to overcome calcium related diseases.

The concentration of lithium in the Water, ethanolic and DCM extracts of Bombax ceiba were found to be $(31,25$ and $11 \mathrm{ppm})$ respectively and is within the range set by FAO/WHO., 1984 [10].

\section{Conclusion}

The plant screened for phytochemical constituents seemed to have the potential to act as a source of useful drugs and also to improve the health status of the consumers as a result of the presence of various compounds that are vital for good health. The plant in reference showed that in addition to the ornamental purpose the ceiba species posses a good quality of phytochemicals which directly or indirectly help in the health maintenance of living beings. In conclusion it can be mentioned that plants bear a good potential to overcome every problem in a human body. The concerned plant possesses a high degree of value as source of antidiabetic drug. Every type of activity concerned with a plant is due to the phytochemicals which remain in built within these plants. The antidiabetic activity of the plant is due its potential in habit amylase productions, which in turn leads to non decomposition of higher carbohydrates into lower there by make blood glucose leval within required limit of the cell.

The presence of metal constituents in the plant species could be beneficial because these metals form the base for the development of higher moiety of phytochemical and the change in the state of higher phytochemicals is being overcome by the metal which lies at the central moiety of the higher phytochemicals. So concerned plant flowers should be consumed more and more to over various types of human disorders.

\section{References}

1. Rawat Mukesh, Parmar Namita (2013) Medicinal Plants with Antidiabetic Potential. American-Eurasian J Agric \& Environ Sci 13(1): 81-94.

2. SK Verma, Vartika Jain, SS Katewa (2011) ANABOLIC EFFECT OF BOMBAX CEIBA LINN. ROOT IN IDIOPATHIC INVOLUNTARY WEIGHT LOSS - A CASE STUDY. Journal of Herbal Medicine and Toxicology 5(1): $1-5$.

3. Verma Rameshwar, Devre Kishor, Gangrade Tushar ,Gore Siddharth, Gour Sudarshan (2014) A Pharmacognostic and pharmacological overview on Bombax ceiba. Scholars Academic Journal of Pharmacy (SAJP) 3(2): 100-107.

4. Bhushan Gandhare, Nikhil Soni, Hemant J. Dhongade (2010) In Vitro Antioxidant Activity of Bombax Ceiba. International Journal of Biomedical Research 1(2): 31-36.

5. Roja Sri Donipati, MV Rama Rao, P Subhasini (2014) Antimicrobial Activity of Flower Extracts Of Bombax Ceiba On Coli Forms. world journal of pharmaceutical research 4(3): 1466-1470.

6. Garg Nitika, Meena Ajay,Nain Jaspreet (2011) Evaluation of physicochemical and preliminary phytochemical studies on the root of Bombax ceiba Linn. International journal of research in ayurveda and pharmacy 2(3): 924-926.

7. Laila A Shekib, Samir M El-Iraqui, Taisser M Abo-Bakr (1988) Studies on amylase inhibitors in some Egyptian legume seeds. Plant Foods Human Nutr 38(4): 325-332.

8. Krishnaveni S, B Theymoli, Sadasivam S (1984) Phenol Sulphuric Acid method. Food Chem 15: 229.

9. Shai LJ, P Masoko, MP Mokgotho, SR Magano, MA Mogale, et al. (2010) Yeast alpha glucosidase inhibitory and antioxidant activities of six medicinal plants collected in Phalaborwa, South Africa. South African J Bot 76(3): 465 - 470.

10. FAO/WHO. (1984) Contaminants. In Codex Alimentarius, vol. XVII, Edition 1. FAO/WHO, Codex Alimentarius Commision, Rome.

11. Charlene J, Nuble (2005) Potassium and Its Benefits to the Human Body By.

12. Recommended Dietary Allowances. (1989) Subcommittee on the Tenth Edition of the RDAs Food and Nutrition Board Commission on Life Sciences, $\left(10^{\text {th }}\right.$ edn), National Research Council, and National Academy Press, Washington, DC, USA, pp. 174-184.
Your next submission with Juniper Publishers will reach you the below assets

- Quality Editorial service

- Swift Peer Review

- Reprints availability

- E-prints Service

- Manuscript Podcast for convenient understanding

- Global attainment for your research

- Manuscript accessibility in different formats

( Pdf, E-pub, Full Text, Audio)

- Unceasing customer service

Track the below URL for one-step submission https://juniperpublishers.com/online-submission.php 